\title{
Pendidikan Karakter dalam Pembelajaran Sejarah Selama Pandemi Covid-19
}

\author{
Muhammad Ihsan Karmedi ${ }^{1 \bowtie}$ Firman $^{2}$, Rusdinal ${ }^{3}$ \\ $(1,2,3)$ Pendidikan Ilmu Pengetahuan Sosial, Universitas Negeri Padang
}

$\triangle$ Corresponding author

[Karmediihsan@gmail.com]

\begin{abstract}
Abstrak
Artikel ini mengutarakan dan menguraikan pendidikan karakter dalam pembelajaran sejarah selama pandemi Covid-19. Strategi yang digunakan dalam penulisan ini adalah metode penelitian kualitatif. Artikel ini bertujuan untuk mengungkapkan pendidikan karakter dalam pembelajaran sejarah pada saat pandemi covid-19 yang hingga saat ini masih terus berlanjut. Agar pembelajaran sejarah dalam menggunakan teknologi jarak jauh tetap berlangsung dengan lancar, guru perlu menanamkan pendidikan karakter kepada peserta didik dengan cara saling menguatkan antara guru dengan siswa, juga sesama antar siswa. Pembelajaran jarak jauh menjadi solusi agar pembelajaran sejarah tetap berlangsung seperti biasa meskipun dilakukan di rumah masing-masing.
\end{abstract}

Kata Kunci: Pendidikan karakter; pembelajaran sejarah

\begin{abstract}
This article outlines and outlines character education in history learning during the Covid-19 pandemic. The strategy used in this paper is a qualitative research method. This article aims to reveal character education in learning history during the Covid-19 pandemic, which is still continiuing. In order of history learning in using distance technology to continue smoothly, teachers need to instill character education in students by strengthening each other between teachers and students, as weel as among students. Distance learning is a solutionso that history learning continues as usual even though it is done at home.
\end{abstract}

Keyword: Character education; history learning

\section{PENDAHULUAN}

Virus Corona atau Corona Virus Disease (Covid-19) tengah menjadi ancaman yang serius dan tengah dihadapi oleh negara-negara di dunia, termasuk Indonesia. Virus ini menyerang sistem pernafasan yang ditandai dengan demam, batuk, flu, dan sulit bernafas. Virus ini ditemukan pertama kali di Wuhan, Provinsi Hubei, Republik Rakyat Tiongkok pada Desember 2019, dan meluas hingga seluruh dunia dan menjadi Pandemi hingga saat ini. Kasus covid-19 di Indonesia pertama kali ditemukan pada Maret 2020 di Depok, Jawa Barat. Sampai saat ini (2 Februari 2021), kasus positif di Indonesia mencapai 175.349 kasus dengan terkonfirmasi mencapai 1.089.308 kasus. Itu pun kalau ditambah dengan kasus di seluruh dunia dengan mencapai 103.938.208 kasus. Jumlah ini menjadikan Pandemi Covid 19 sebagai pandemi mematikan nomor 2 di dunia setelah Flu Spanyol yang terjadi pada 1918-1920 dan menewaskan nyaris 100 juta orang.

Virus ini berdampak bagi berbagai sektor, mulai dari ekonomi dan juga pendidikan. Guna mencegah penularan virus covid-19 tidak meluas, pemerintah memberlakukan bekerja dari rumah (work from home) bagi para pekerja yang berkerja di perkantoran-perkantoran. Khusus untuk pendidikan, sesuai dengan edaran pemerintah Nomor 4 tahun 2020 tentang pelaksanaan kebijakan Pendidikan dalam masa darurat Penyebaran Corona Virus Disease (covid-19), pemerintah melalui Kementerian Pendidikan dan Kebudayaan mulai memberlakukan Belajar dari Rumah (learn from home). Ini berarti seluruh aktifitas kegiatan belajar mengajar mulai dari tingkat TK hingga perguruan tinggi dipindahkan ke rumah masing-masing tanpa bermaksud untuk meliburkan aktifitas kegiatan belajar mengajar.

Pembelajaran yang dipindahkan dari sekolah ke rumah masing-masing bertujuan untuk mencegah siswa dan siswi terpapar virus covid-19 sekaligus menghindari sekolah menjadi klaster baru penyebaran covid-19, membuat peserta didik dan guru harus menyiapkan berbagai peralatan agar kegiatan pembelajaran berjalan dengan lancar, seperti Hp Smartphone, Laptop, dan kuota untuk melakukan pembelajaran. Di era teknologi saat ini, begitu banyak berbagai aplikasi guna mendukung kegiatan belajar mengajar seperti Zoom, Whatsapp, Google Classroom, Webex, dan lain-lain. Namun, terkadang Pembelajaran dengan sistem daring ini bukan tanpa kekurangan atau masalah, salah satunya yaitu biaya yang dibutuhkan untuk sekedar membeli kuota untuk melakukan kegiatan belajar mengajar 


\section{METODE PENELITIAN}

Penelitian yang digunakan dalam penulisan ini yakni penelitian kualitatif. Penelitian ini menghendaki naturalisasi dalam pemerolehan data. Metode ini bekerja dengan cara alami dan menyajikan temuan sesuai apa adanya atau dengan kata lain sesuai data yang ditemukan di lapangan. Penelitian kualitatif untuk menggambarkan sesuatu yang bersifat nyata yang benar-benar terjadi dari suatu peristiwa atau yang menjadi objek eksplotasi (Moleong, 2017). Walaupun secara redaksional, uraian temuan penelitian lebih banyak menggunakan redaksi kalimat yang dibangun oleh peneliti sendiri, tetapi tetap semaksimal mungkin akan mendasarkannya kepada fenomena atau fakta yang ada.

Penelitian ini termasuk studi kepustakaan (library research), yang merupakan kegiatan perkembangan latihan mengidentifikasi dengan teknik pengumpulan informasi perpustakaan. Studi pustaka adalah strategi pengumpulan informasi yang bertujuan untuk menemukan informasi melalui catatan, baik arsip tersusun maupun laporan elektronik yang dapat menopang pengolahan penulisan.

\section{HASIL DAN PEMBAHASAN}

Pendidikan karakter merupakan suatu pengaturan penanaman nilai-nilai karakter kepada individu sekolah yang menanamkan kepercayaan, kewaspadaan, dan kesiapan, serta kegiatan untuk melakukan sifatsifat tersebut baik kepada Tuhan yang Maha Esa, diri sendiri, lingkungan sekitar, iklim, dan etnis sehingga menjadi manusia yang insan kamil (Muslich, 2011). Dalam pengertian lain, pendidikan karakter dicirikan sebagai pengajaran yang menciptakan nilai-nilai karakter pada diri siswa sehingga mereka memiliki nilai dan karakter sebagai karakternya sendiri, menerapkan kualitas tersebut dalam kehidupannya sendiri, sebagai warga negara, dan dan pribadi yang tegas, patriot, bermanfaat, dan inovatif (Abidin, 2012).

Pembelajaran Jarak jauh (PJJ) merupakan proses kegiatan pembelajaran yang tidak mempertemukan dua individu secara langsung antara instruktur dan siswa. Korespondensi terjadi dalam dua cara yang dihubungkan dengan media seperti PC, radio, telepon, web, video, dll. (Munir, 2012: 16). Dalam pembelajaran jarak jauh siswa belajar tanpa mendaptakan pengawasan secara langsung dari instruktur atau mentor yang tersedia di ruang pembelajaran. Namun, siswa mendapatkan pengaturan, arahan dari lembaga yang mengawasi pembelajaran dar jarak jauh.

Pandemi Covid-19 yang menjangkiti Negara-negara di seluruh dunia, termasuk Indonesia membuat pembelajaran yang sebelumnya dilakukan secara tatap muka berubah menjadi pembelajaran jarak jauh. Hal ini memaksa pihak sekolah untuk menerapkan kegiatan pembelajaran secara daring. Karena era saat ini adalah era teknologi, berbagai aplikasi menjadi pendukung Guru dalam memberikan pengajaran. Seperti yang telah disebutkan di atas, sistem pembelajaran daring ini bukannya tanpa memiliki permasalahan.

Dari pihak peserta didik, pembelajaran jarak jauh ini memerlukan berbagai perlengkapan seperti smartphone, dan kuota. Bagi peserta didik yang orangtua nya berkecukupan atau kaya, hal itu tidaklah menjadi masalah. Akan sangat berbeda ceritanya apabila peserta didik yang perekonomiannya pas-pasan, hal itu menjadi sangat sulit dikarenakan pada umumnya harga dari smartphone cukuplah mahal, belum lagi kuota yang sangat memberatkan peserta didik itu sendiri. Masalah belum sampai di situ, pembelajaran jarak jauh ini terkadang tak maksimal gara-gara sinyal yang terkadang down atau tidak ada, peserta didik tentu harus pergi ke tempat yang jauh agar bisa mendapatkan sinyal.

Bukan hanya pihak siswa yang mengalami hal itu. Guru pun juga mengalami hal serupa. Hal ini sangatlah tidak terduga bagi guru yang masih buta akan teknologi, ia akan kesulitan dalam memberikan pembelajaran. Selain harus menyiapkan pembelajaran, guru juga harus pandai mengoperasikan aplikasiaplikasi seperti Zoom, Webex, dan lain-lain. Akan berbeda cerita apabila guru yang cukup pandai dalam mengoperasikan aplikasi-aplikasi yang telah disebutkan sebelumnya.

Bagi guru sejarah, pendidikan karakter dalam pembelajaran sejarah selama pandemi covid-19 memberikan tantangan tersendiri. Sebab, situasi, kondisi, dan keadaan Pembelajaran jarak jauh akan terasa berbeda jika dibandingkan dengan Pembelajaran tatap muka. Pembelajaran jarak jauh menyebabkan siswa dan siswi merasa bosan. Maka dari itu Guru harus memahami bahwa pendidikan karakter menjadi kunci dalam kesuksesan Pendidikan di Indonesia. Guru tidak hanya menjalankan tugasnya dalam mencerdaskan generasi penerus bangsa dari segi akademik, tetapi juga meningkatkan kecerdasan spiritual dan kecerdasan emosional peserta didik.

Sebelum pembelajaran sejarah dimulai, Guru bisa memotivasi para siswa agar tidak patah semangat meskipun pembelajaran hanya dilakukan lewat daring guna menghindari penyebaran virus covid-19. Seperti Guru mengajak murid-murid menyanyikan lagu-lagu semangat dan bisa juga yel-yel semangat agar siswa dan siswi tidak merasakan situasi berbeda dan tetap merasakan kebersamaan seperti halnya ketika pembelajaran tatap muka. Selain itu, guru juga menguatkan mental siswa dan siswinya agar tidak merasa down dan tetap mengontrol emosi siswa dan siswinya meskipun pandemi covid-19 ini belum berlalu.

Dari sisi spiritual, guru mengajak siswa dan siswi untuk melakukan doa sebelum pembelajaran jarak jauh dimulai, seperti ketika pembelajaran tatap muka. Tujuannya adalah agar pembelajaran jarak jauh berjalan dengan lancar dan nyaman. 
Peran orang tua juga mendukung pendidikan karakter anak-anaknya ketika mengikuti pembelajaran jarak jauh. Karena orang tua atau keluarga menjadi tempat atau lembaga anak menerima pendidikan ketika mereka lahir ke dunia dan pertama kali menghirup udara. Benar-benar focus menyemangati dan mengajarkan anak di rumah adalah komitmen setiap orang tua dengan tujuan akhir yaitu membentuk karakter anak (Mutiah, 2012). Orang tua dipercaya membantu anak dalam menyiapkan media yang akan digunakan anak, mengikuti interaksi pembelajaran dan banyak lagi yang dapat membentuk ukuran mendidik dan belajar di rumah dengan sistem pembelajaran jarak jauh.

Bantuan dari orang tua untuk pembelajaran dari rumah selain membentuk anak-anak dalam melakukan pembelajaran juga akan membangun hubungan antara orang tua dan anak menjadi lebih dekat. Hubungan yang dekat ini akan membuat seorang anak semakin mengembangkan kreativitasnya dengan kreasi yang bermanfaat (Prianto, 2020). Peran pendidik dan wali murid sangat dibutuhkan dalam mendukung interaksi pengajaran dan pembelajaran anak-anak yang dilakukan di rumah. Keduanya harus bekerja sama untuk mengembangkan latihan belajar anak.

\section{SIMPULAN}

Pendidikan karakter dalam pembelajaran Sejarah selama pandemi Covid-19 memberikan tantangan tersendiri bagi guru Sejarah. Sebab seorang guru selain menyiapkan bahan materi dan menguasai aplikasiaplikasi guna mendukung pembelajaran jarak jauh, guru juga menyiapkan psikis dan kematangan emosi siswa dan siswinya, serta memberikan semangat. Selain guru, peran orang tua siswa dan siswi juga mendukung pendidikan karakter anak dalam menghadapi pembelajaran. Orang tua dan guru merupakan kolaborasi yang sangat mendukung dan menentukan maksimalnya pembelajaran anak.

\section{UCAPAN TERIMA KASIH}

Terima kasih yang sebesar-besarnya kami ucapkan kepada Dosen pembimbing dan semua pihak yang telah memabntu sehingga artikel ini dapat dipublikasikan.

\section{DAFTAR PUSTAKA}

Abidin, Yunus. 2012. Model Penilaian Otentik dalam pembelajaran Membaca Pemahaman Berorientasi Pendidikan karakter. Bandung: Universitas Pendidikan Indonesia.

\section{Covid19.go.id. Diakses pada 2 Februari 2021 pukul 14.31 WIB.}

Moleong, L. J. 2017. Metodologi Penelitian Kualitatif (Edisi Revisi). Bandung: PT Remaja Rosdakarya. Munir. 2012. Pembelajaran Jarak Jauh Berbasis Teknologi Informasi dan Komunikasi. Bandung: Alfabeta.

Mutiah, D. 2012. Psikologi Bermain Anak Usia Dini. Jakarta: Kencana.

Prianto, C. 2020. Pembelajaran bermakna di Tengah Covid-19. Surabaya: Yayasan Kita Menulis. 